\title{
水制背後の流れ構造に及ぼす透過流の影響 \\ EFFECTS OF PERMEATING FLOW ON FLOW STRUCTURES BEHIND SPUR DIKES
}

\author{
冨永晃宏 $1 \cdot$ 長尾正志 $2 \cdot$ 長坂剛 3 \\ Akihiro TOMINAGA, Masashi NAGAO and Go NAGASAKA \\ 1正会員 工博 名古屋工業大学教授 工学部社会開発工学科（广466-8555 名古屋市昭和区御器所町） \\ 2 フ土哙員工博 名古屋工業大学教授 工学部社会開発工学科 ( \\ 3学生会員名古屋工業大学大学院 工学研究科社会開発工学専攻 (下466-8555 名古屋市昭和区御器所町)
}

\begin{abstract}
In recent years, spur dikes are expected to demonstrate various functions. Permeating flow through the spur dike can control the flow field, structures of separation vortex and bed configuration around the spur dikes. In this study, velocity fields behind the solid, straightly permeating and inclined permeating spur dikes are measured and compared. The resistance and scour depth at the head of the spur dike are reduced by the permeating flow through the dike. Spur dikes with inclined permeating flow were proved to have several advantages. The inclined permeating flow reduces the strength of the separation vortex, keeping almost similar deceleration effect and reattachment length. Furthermore, it decreases the turbulence intensities behind the spur dike and maintains relatively lower velocity over a long distance behind the spur dike, even in the case of movable bed.
\end{abstract}

Key Words : spur dike, permeating flow, flow structure, separation, vortex, movable bed

\section{1. 序論}

水制は流れに対する粗度効果と水はね効果により 河岸浸食防止あるいは護岸の破損防止などを主目的 に設置されるものであるが，構造物周辺の流れが多 様なため河岸植生や水生生物にとって良好な㻴境が 創造でき, 生態系の保全・育成に大きな効果がある ことが注目されてきている. 従来, 経験に基づき河 川の特性に合わせて様々なタイプの水制が用いられ ている ${ }^{1)}$. 水制は非常に多くの設計項目を要し, 流 れと河床変動に対する影響が複雑であるため，その 最適な設計法を確立するのは未だに困難である．河 道湾曲部などの水制配置による水衝部の制御に関す る研究や2),3), 各種水制群を有する開水路流れの流 動形態と抵抗特性に関する研究4),5,,6,7), また, この ような水制周辺流れの数值計算に関する研究8),9)等 が盛んに行われており，流れに対する抵抗やマクロ な流動変化についてはある程度予測可能になってき ていると言える．しかし，水制の形状や形式に対す る水制背後の乱れや混合機構および土砂堆積機構等 の応答変化特性についてはいまだ不明な点が多く, 検討の余地が残されている。楊・石井 ${ }^{10}$ は河川景観 の面から水制のタイプと代表的土砂堆積の関係を論 じているが，水理学的にこのような水制の役割を合
理的に説明できていないように思われ，水理面から のさらなる研究が必要であると考える.

本研究では, 流下方向に対して角度を有するスリ ットによって水制背後の渦や河床変動をコントロー ルすることのできる透過型水制に注目し，その水理 的特性を明らかにすることを目的とする。このタイ プの水制は，文献11)にハイドロバリア水制として 紹介されているものである，八イドロバリア水制は， 流れに直角方向に出された水制構造内部に透過流あ るいは通水路部分を有し，この透過流部分は構造体 の軸に対して $\alpha=30^{\circ} \sim 40^{\circ}$ の角度で設けられるもの である，文献11)によれば，図一1 (a)〜(c)に示すよ うなタイプの水制の例が挙げられている. このハイ ドロバリア水制の機能として，次のことが考えられ る. 水制構造内の透過流部を通過する水流は河心方 向へ曲げられ，河岸から遠ざかる．八イドロバリア 水制頭部の前方を通過する水流は，偏位現象により 逆に河岸方向へ曲げられる. このべクトルの異なる 二つの水流が，構造体の下流で再び合流して互いに 激しくぶつかり合うことにより，エネルギー逸散を 促進するというものである. しかも，二つの水流の 合成ベクトルは，河岸に対してより鈍い角度となり， また水流の河岸への到達点は不透過水制よりさらに 下流側へずれるため，水制間距離をより大きく取る 


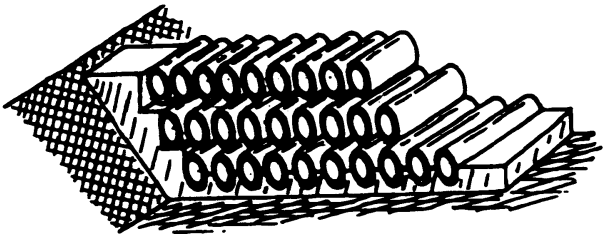

(a) 円管によるもの

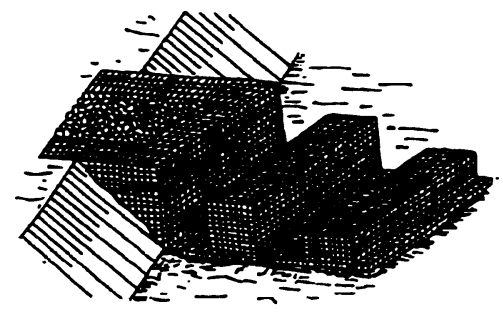

(b)ふとん䈏によるもの

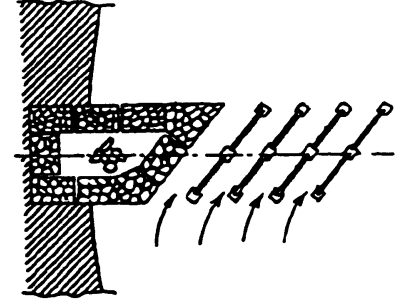

(c) コンクリート板によるもの

图ー1 ハイドロバリア水制の例（イヴァン・ニキティン11)より抜㮖）

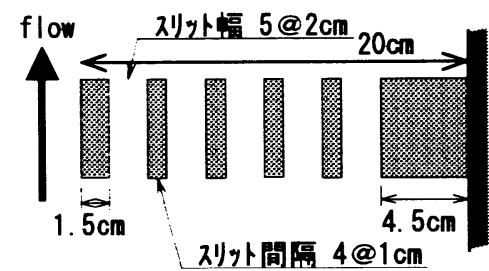

(a)ケースS1

$35^{\circ}$

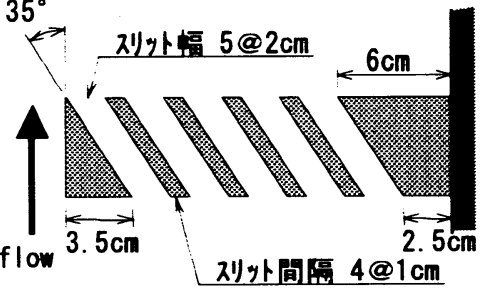

(d)ケース $\mathrm{H} 1$

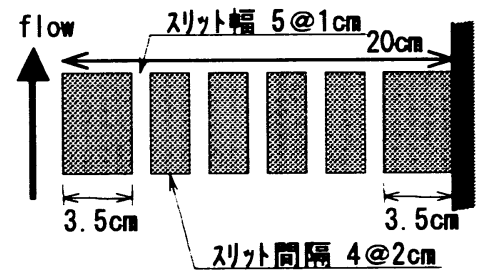

(b)ケース 22

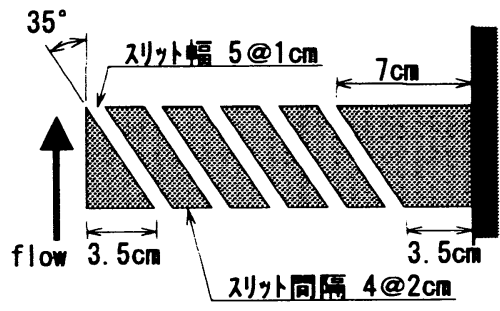

(e) ケース $\mathrm{H} 2$

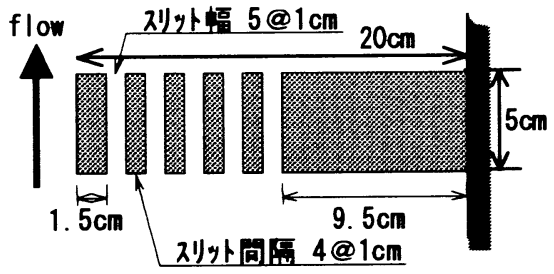

(c) ケースS3

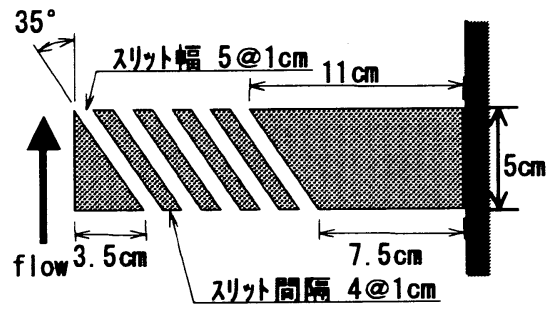

(f)ケース $\mathrm{H3}$

\section{图一2 透遏水制断面图}

ことができる.さらに透過流の存在により水制頭部 の洗掘が小さくなることが期待される. 以上のよう な長所を有すると考えられるハイドロバリア水制で あるが，その水理機能については不明な点が多い. 本研究は，水制構造内部に透過部を設けた実験によ って，透過流が水制背後の流れに及ぼす影響と透過 流に角度をつけたときの効果を検討したものである. 透過水制の透過流に着目した研究としては, 福岡ら

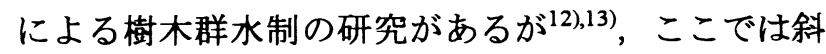
め方向の透過流の影響を検討した点が異なる.

\section{2. 実験装置および方法}

実験は，長さ $13 \mathrm{~m}$, 幅 $60 \mathrm{~cm}$ の勾配可変型開水路に おいて水制模型を設置して行われた。実験に用いた 水制模型の形状は，長さ $20 \mathrm{~cm}$, 幅 $5 \mathrm{~cm}$ の非越流不透 過型水制を基本とし（ケースNS），この基本構造 に対してスリットを入れたものを透過水制モデルと した。透過流部は流下方向に対して平行なケース (直進透過型)と，流下方向となす角 $35^{\circ}$ の斜めのケー ス(斜め透過型)を設定した。水制全長に対するスリ ット幅の比を $1 / 2$ と $1 / 4$ の 2 種類設定し，1/4のものに ついてはさらにスリット位置を水制全体型と先端部 集中型の 2 種類設定した。水制はいずれも非越流型 としている. 以上の水制模型の形状を図一 2 に示す. 水制は水路上流端から $6 \mathrm{~m}$ の位置に 1 基設置した.
水路勾配は $1 / 2000$, 流量は $7200 \mathrm{~cm}^{3} / \mathrm{s}$, 水深は下流部 を堰上げ，水制設置断面で $6 \mathrm{~cm}$ となるようにした。

流速計測には， 2 成分 I 型電磁流速計（東京計測 製）を用い，主流速と横断方向流速を計測した。座 標軸は流下方向を $x$, 横断方向を $y$, 鉛直方向を $z$ と

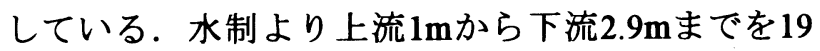
断面に分割し, 横断方向に12点, 鉛直方向に2点, 合計448点で計測を行い, サンプリング周波数 $100 \mathrm{~Hz}$ で41秒計測したデータについて解析した. また，水 深はデジタルポイントゲージにより計測した.

水制背後の大規模平面渦構造の周期的挙動を調へ るために，おがくずを水面に散布し表面流況をビデ オカメラによって撮影する可視化実験を行った. 得 られた画像から相互相関法によってP I V画像解析 を行い，流速べクトルを計算するとともに，瞬間の 流線を求め, その時間変化を検討した. ただし，水 制背後の渦構造の流下方向長さは200〜300cmもあ るため 1 画面で捉えるのが困難であったため， 2 3 画面に分けて撮影した.

次に，水制周辺の河床変動への影響を調へるため 平均粒径 $0.05 \mathrm{~cm}$ の砂を水制上流 $1.4 \mathrm{~m}$ 加万下流 $4.0 \mathrm{~m}$ ま で厚さ $10 \mathrm{~cm}$ で敷き詰め移動床とし，通水を120分間 した後最終洗掘形状を計測した. また河床変動によ る流れ特性の変化を明らかにするために, 固定床の 場合と同様に電磁流速計によって $\mathrm{z}=3 \mathrm{~cm}$ の 1 断面に おいて流速計測を行った. 


\section{3、点計測による実験結果}

図一 3 に全ケースの水深平均された平面流速べク トルと流線を示す，不透過型のケースNSでは，主 流が水制先端部から主流域側に大きく水はねされて 膨らみ，下流で再び水制域側へ戻る流れを伴う湾曲 した流れ構造を示す．その結果，水制背後に水制長 さよりも大きな幅を持つ剥離渦を形成する．直進透 過型で透過面積比 $1 / 2$ のケース 1 亿゙は水制先端で水 はねは見られるものの，水制を透過する流れが存在 するため，水制根元部ごく近傍を除いて水制背後に 逆流域は見られない。直進透過型で透過面積比 $1 / 4$ のケースS2では，透過流の減少によってS1に比べて 水制背後の流速が減少する．直進透過であるにもか かわらず，水制内を通過した流れは主流域側へ曲げ られ，小さな剥離渦が形成されている．同じく透過 面積比 1/4で水制先端部を透過型としたケースS3で は，水制根元の不透過部の増大によってより明確な 剥離渦を形成しているが，水制背後の减速や流線形 状はS2 とほとんど変化がない，次に，斜め透過型で 透過面積比 $1 / 2$ のケース H1では，水制先端部の水は ね角度が不透過型より小さくなり，下流での水制域 側への戻り流れも小さくなる. 透過流の影響によっ て剥離渦の主流域側への膨らみがなくなり, 逆流の 強度も减少しているが, 剥離渦は流下方向に長く存 在している，透過面積比を $1 / 4$ としたケース $\mathrm{H} 2 て ゙ は ，$ 水はね角度が若干大きくなり剥離渦の幅も大きくな る. 逆流強度は小さくなるが, 再付着点距離は大き くなる．透過部を先端に設けたケースH3では，さら に水はね角度が大きくなり不透過型に近づくものの， 剥離渦の大きさはH2とほぼ同程度である.

図一 4 にケース $\mathrm{S} 2$ と $\mathrm{H} 2$ を除く各ケースの水深平 均主流速の流下方向分布を示す，ケース $\mathrm{S} 2, \mathrm{H} 2$ は それぞれS3，H3とほぼ同様の傾向を示した。 また， 表一 1 に水制周辺流れの特性量と考えられる，流速 分布から計算される水制内部の透過流量率 $\beta$ の值, 水制前後の水位差 $\Delta \mathrm{h}$ （水制前面 $10 \mathrm{~cm}$ と水制背面 $10 \mathrm{~cm}$ の平均水樑の差），水制先端の水はね角度 $\alpha$, 再付着点距離 $\mathrm{L}$, 水制域側壁近傍の逆流速度の最大 值 $\mathrm{U}_{\mathrm{b}}$, 計測範囲最下流の主流速の横断方向偏差 $\Delta \mathrm{U}_{\mathrm{d}}$ を示す. 再付着点距離Lは図一 4 から水制側側壁に 最も近い測線の流速 0 をクロスするx座標を再付着 点として求めた。実際の透過流量率は透過面積比 $1 / 2$ で約 $20 \%$ ， 流水断面積に対する水制内透過部の 面積比 $1 / 5$ に相当する流量が通過していることがわ かる. 斜め透過型は若干これより少なくなっている。 透過面積比 $1 / 4$ では流水断面積比 $1 / 9$ よりも小さな值 となり，これも斜め透過型の方が小さい. 水制前後 の水位差は透過型でかなり減少し, 抵抗が減少する ことを示している. 水はね角度 $\alpha は$ 透過部を設ける ことによりかなり減少する．直進透過型では透過面
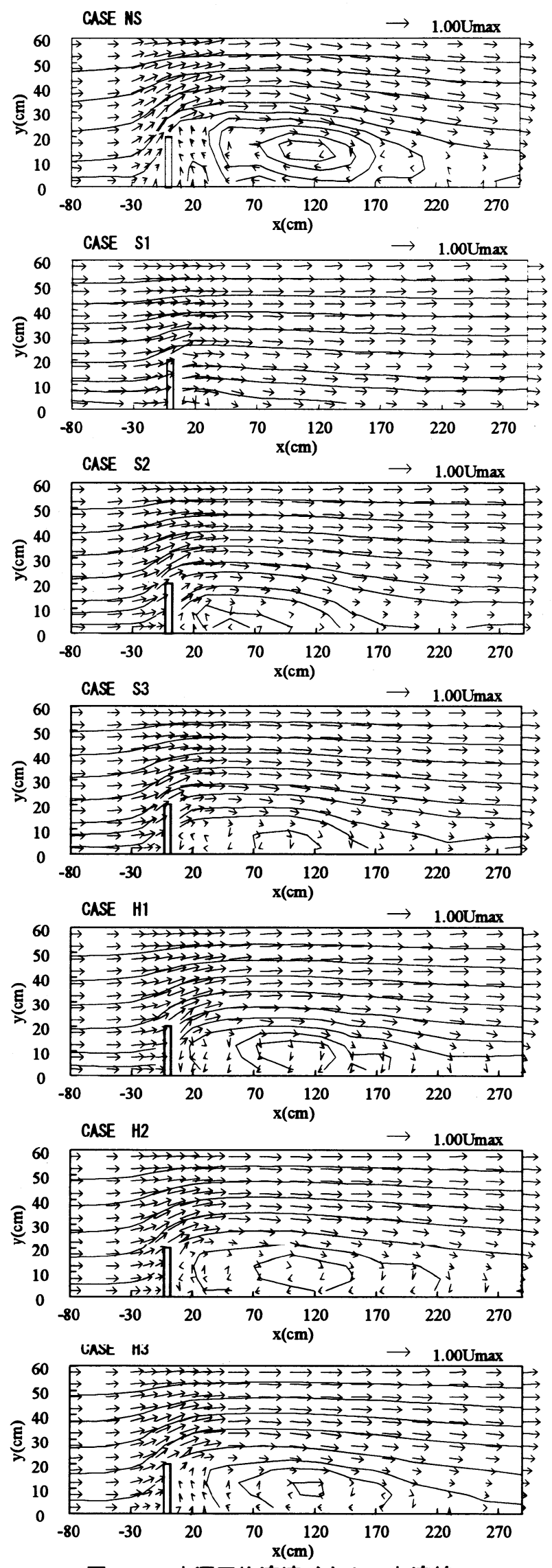

图一3 水深平均流速ベクトルと流線

積比 $1 / 4$ で約 $15^{\circ}$ と不透過の $1 / 2$ 程度となる. 斜め透過 型では透過面積比によって余り変化せず, $20^{\circ}$ 程度 となる. 再付着点距離は, 不透過型で $\mathrm{L}=250 \mathrm{~cm}$ とな 
CASE NS

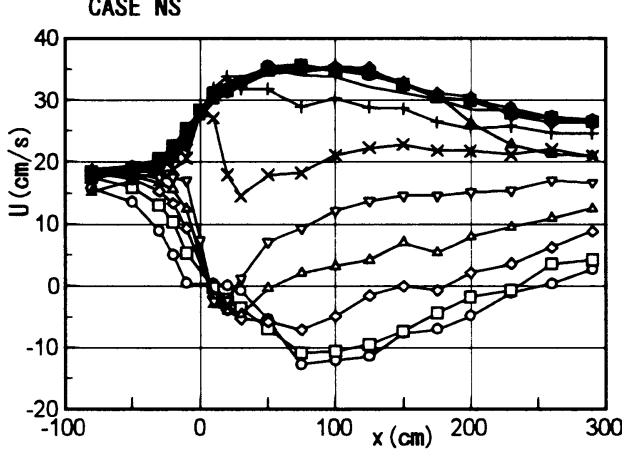

CASE S1

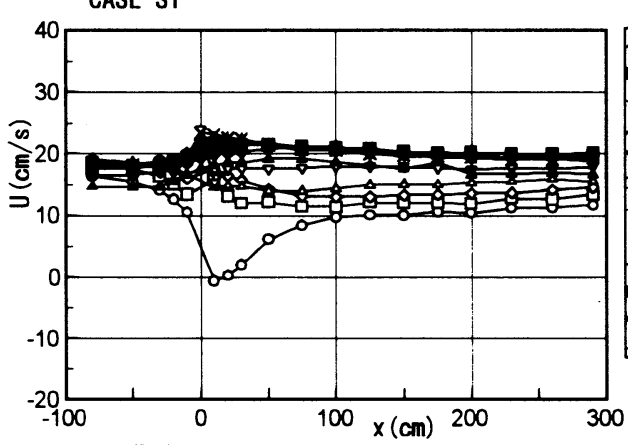

CASE S3

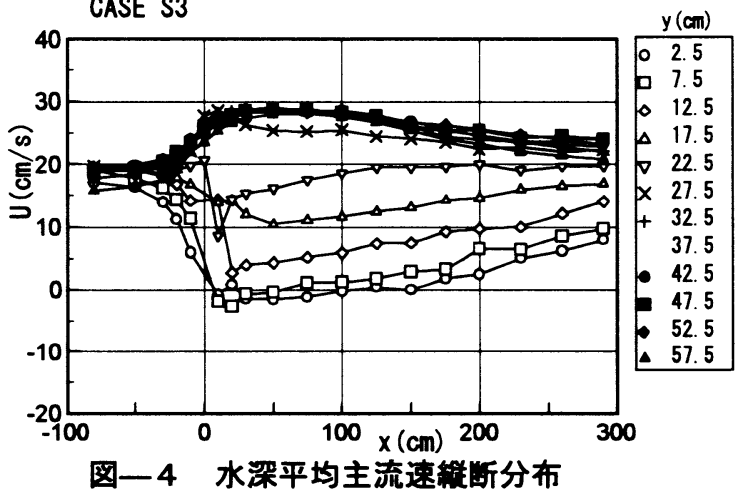

り水制長さの12.5倍に達する. 直進透過型では当然 小さくなるが，斜め透過型では不透過型とさほど変 わらない再付着点距離を有する．ただし，逆流の最 大值 $\mathrm{b}_{\mathrm{b}}$ みると，斜め透過型では $4 \mathrm{~cm} / \mathrm{s}$ から $6 \mathrm{~cm} / \mathrm{s}$ と 不透過型の $1 / 2$ に減少している. 主流域の最大流速 $\mathrm{U}_{\max }$ も不透過型より $13 \%$ 程度减少し，全体として主 流速の横断方向偏差はかなり減少している．直進透 過型の透過面積比 $1 / 4$ のケースではU $\mathrm{U}_{\mathrm{b}}$ は約 $1 / 5$ に減少 し, $U_{\max }$ は約 $20 \%$ 减少している. 最後に横断方向偏 差 $\Delta \mathrm{U}_{\mathrm{d}}$ は不透過型と斜め透過型のH2が最も大きく， その他の斜め透過型がこれに次いで大きい，全般に 斜め透過型は不透過型に比べて水制直後の流速変化 は小さいが，再付着点より下流の位置における流速 差はほぼ同程度となり，流速差の回復が遅い，直進 透過型の透過面積比 $1 / 2$ のS1では，水制直後の流速 差も小さいが, この差が下流まで維持されている. これらは水制背後の乱れに関係し, 乱れが弱い場合, 流速差の回復が遅くなるものと考えられる.

図一 5 に不透過型のNSと斜め透過型のH3のレイ ノルズ応力ー $u v$ および乱れ強度 $u^{\prime}, v^{\prime}$ のコンターを 示す。まず不透過型についてみると，レイノルズ応

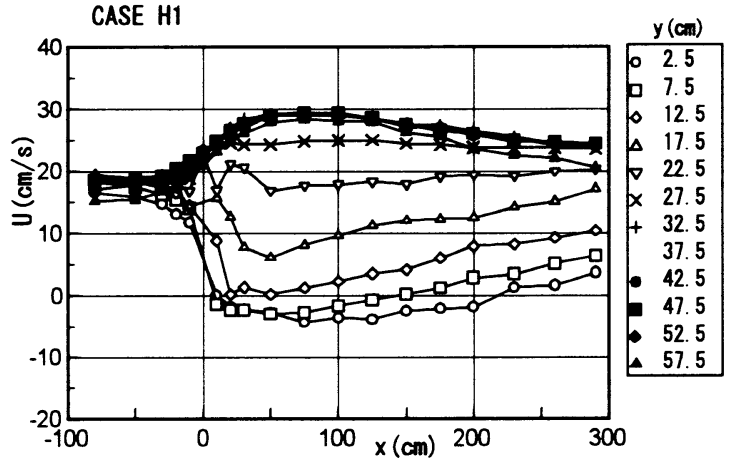

CASE H3

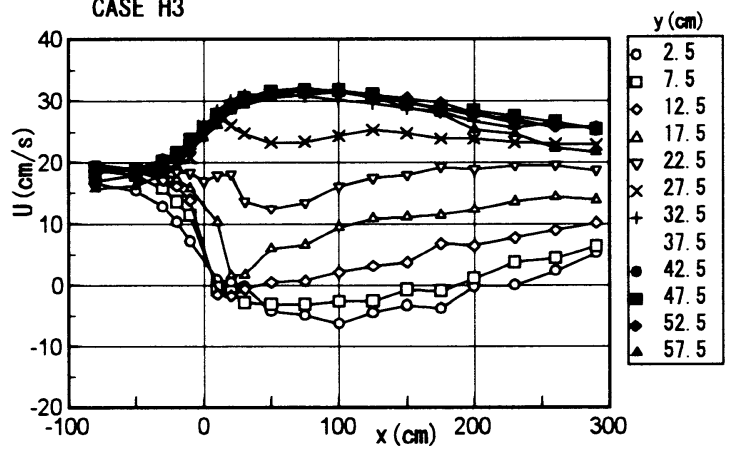

表一 1 水制周辺流れの特性量

\begin{tabular}{|c|c|c|c|c|c|c|c|}
\hline & $\begin{array}{c}\beta \\
(\%)\end{array}$ & $\begin{array}{c}\Delta \mathrm{h} \\
(\mathrm{mm})\end{array}$ & $\begin{array}{c}\alpha \\
\left({ }^{\circ}\right)\end{array}$ & $\begin{array}{c}\mathrm{L} \\
(\mathrm{cm})\end{array}$ & $\begin{array}{c}\mathrm{U}_{\max } \\
(\mathrm{cm} / \mathrm{s})\end{array}$ & $\begin{array}{c}\mathrm{U}_{\mathrm{b}} \\
(\mathrm{cm} / \mathrm{s})\end{array}$ & $\begin{array}{c}\Delta \mathrm{U}_{\mathrm{d}} \\
(\mathrm{cm} / \mathrm{s})\end{array}$ \\
\hline NS & 0 & 8.4 & 33.6 & 255 & 35.7 & -12.8 & 23.8 \\
\hline S1 & 20.6 & 1.6 & 9.7 & 10 & 22.4 & -0.6 & 7.6 \\
\hline S2 & 8.8 & 3.9 & 14.1 & 70 & 28.1 & -2.8 & 14.5 \\
\hline S3 & 8.8 & 3.9 & 15.8 & 105 & 29.0 & -2.6 & 15.3 \\
\hline H1 & 18.6 & 4.1 & 19.3 & 220 & 29.4 & -4.3 & 20.7 \\
\hline H2 & 7.5 & 4.8 & 20.0 & 265 & 31.9 & -6.2 & 23.9 \\
\hline H3 & 8.2 & 5.2 & 16.2 & 210 & 32.0 & -6.3 & 21.2 \\
\hline
\end{tabular}

力 $-\overline{u v}$ は水制先端より約 $7.5 \mathrm{~cm}$ 主流域側, $20 \sim 30 \mathrm{~cm}$ 下流地点に非常に大きな値を持つピークが存在する. ここから下流に向かって剥離剥離渦の外縁に沿って 大きな值の領域が広がる。 これは流速の横断勾配が 大きい領域に対応しているが，下流ではかなりばら つきが大きい，乱れ強度 $\boldsymbol{u}^{\prime}$ はレイノルズ応力のピ 一ク付近を中心として大きな値をとる領域が流下方 向に放射状に広がり，やはり剥離渦外縁に沿ってピ 一クが続く. また, 再付着点の前後において乱れの 大きな領域が存在する.この領域はレイノルズ応力 - $u v に よ る$ 乱れ発生が大きい領域とは対応せず, 剥離渦の大規模な変動によるものと考えられる． $v^{\prime}$ は $\boldsymbol{u}^{\prime}$ と同様に水制先端斜め後方をピークとして大 きな值の領域が広がる. 乱れのピーク值は $\boldsymbol{u}^{\prime}$ とほ ぼ同程度であるが, 再付着点付近に乱れの大きい領 域はみられない，斜め透過型では乱れのピーク位置 が水制側に寄る点を除き乱れの大きい領域は不透過 型とほぼ同じであるが, 大きさはかなり减少してい る. このことは，水制先端を回る流れと水制内を透 過する流れの合流によってエネルギー逸散を促進す るという効果はあまり無いことを意味する. 


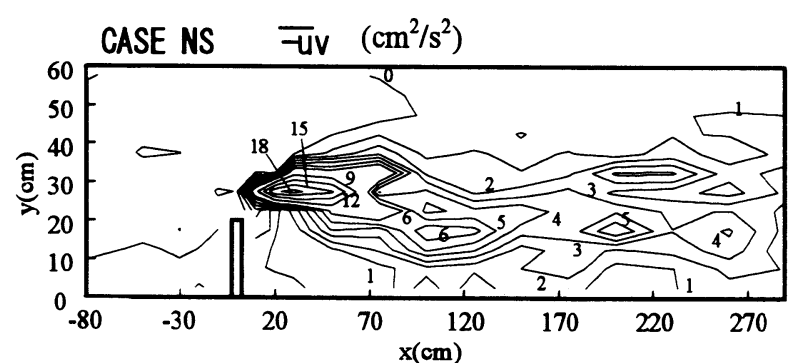

CASE NS U' $(\mathrm{cm} / \mathrm{s})$
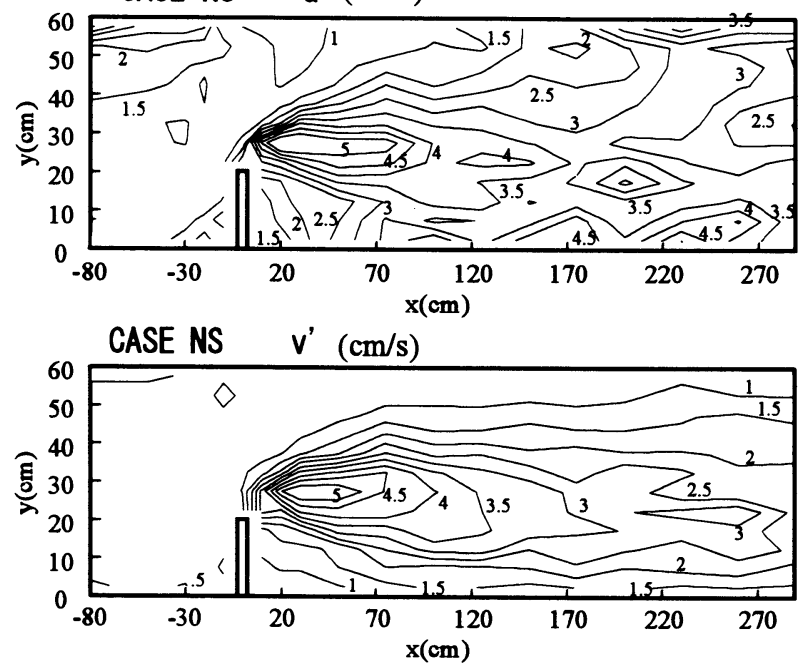

图一5 乱れ特性コンター

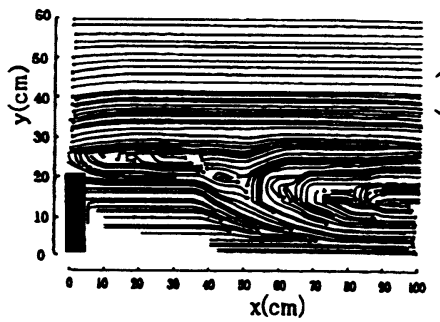

(a)不透過型パターン 1

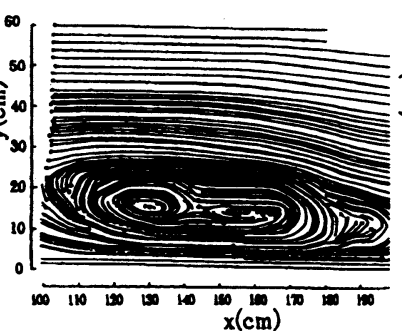

(CASE NS)

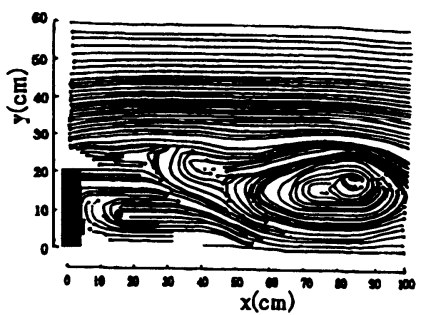

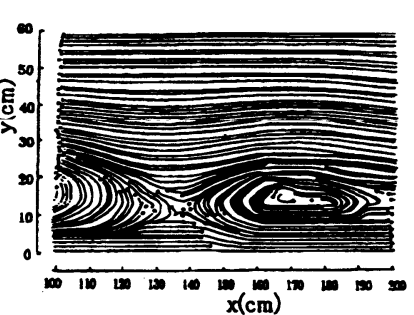

(CASE NS)

图一6 PIV法による表面流の流線群
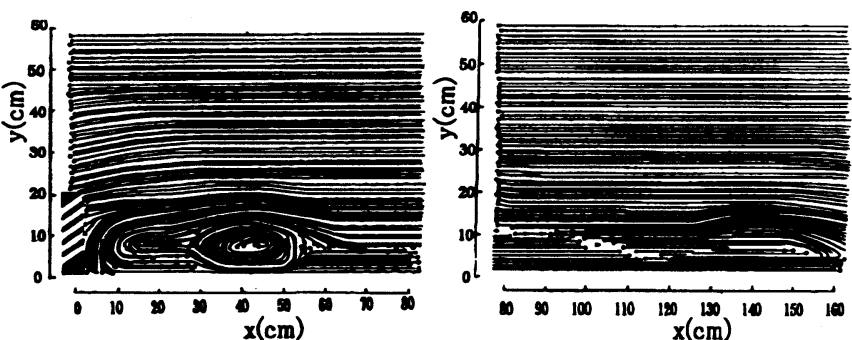

(c)斜め透過型パターン 1 (CASE H1)
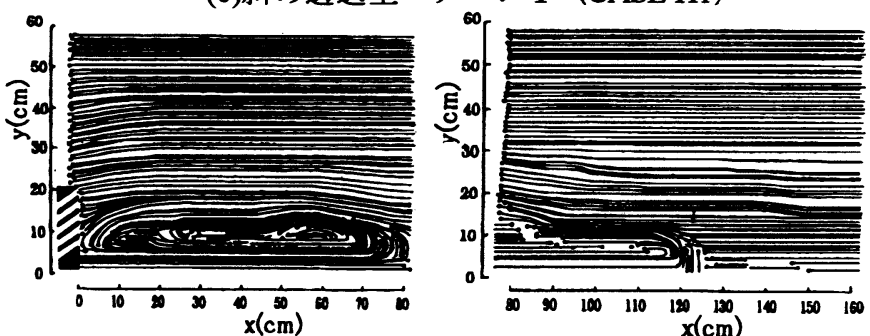

(d)斜め透過型パターン 2 (CASE H1)

\section{4. 可視化計測および河床変動の結果}

図ー6はケースNSとH1のPIV法によって得られた 瞬間平面流速ベクトルから求められた流線群の 1 例 を示す．ビデオ画像エリアは流下方向に $100 \mathrm{~cm}$ が限 界で再付着点までの渦構造を 1 画像で捉えることは できなかったため, 3 画面に分けて撮影した。した がって図は代表的パターンとして連続していると思 われる 2 画像を並べて示したもので，同時刻の瞬間 渦構造ではない。このような制限はあるが, 両者の 渦構造の相違は容易に理解できる。不透過型では (a),(b)に見られるように，水制よりかなり離れた $\mathrm{x}=50 \mathrm{~cm}$ 付近の位置に水制長より幅の大きい渦構造 が存在し，この渦の先端部は水制先端に細長く延び, 先端に接したり離れたりを繰り返している. 水制背 後にはこの大規模渦とは逆向きの渦構造が水制背面 に接して存在する. また, 最下流部の画像は示して いないが, この渦の後端部は時間とともにその長さ

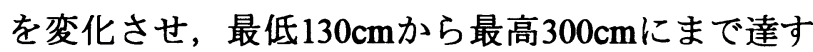
る. 渦がある程度伸張すると中間付近で 2 つの渦に 分裂して流下し（(b)の右の図），その後再び伸張を 始める.このような渦の分裂・伸張の周期は約 6 秒 であった．斜め透過型では, (c),(d)に示すように, 渦は水制背後に密着して安定しており幅は水制長よ 
り小さく扁平な渦となっている. 水制内部の透過流 が安定した剥離渦を維持している。この渦の後端部 は時間によって伸張し後端部が分裂して流される （(c)の右の図）。しかし，下流側の渦は規模も小さ く短時間で消㓕している. この場合も分裂・伸張の 周期は約 6 秒であった. 以上から, 不透過型では水 制先端部からの剥離がせん断不安定渦を引き起こし, これが水制から離れた位置の大規模な渦へと発達す るのに対し，斜め透過型では透過流が主流域一貫入 し水制域の流れを連行することによって，水制に密 着した安定な剥離渦を形成することがわかった.

図一 7 にケースNS, H3の 2 時間通水後の河床高 コンターを示す．不透過型のNSでは水制頭部にお いて $6 \mathrm{~cm}$ 以上もの洗掘が起きており, 水制頭部後方 から対岸にかけて洗掘と峰が交互にできている. 斜 め透過型のH3では最大洗掘深は $8 \mathrm{~mm}$ でかなり洗掘 が小さくなることがわかる.また, 堆積域は不透過 型より主流域側に寄っている，透過面積比の大きい H1および直進透過型ではほとんど洗掘がみられなか った.このように，水制内部に透過流を与えると水 制頭部の洗掘を大幅に軽堿できることがわかった. また, 図一 8 に示す不透過型の河床変動後の流速へ クトルから, 水制先端の洗掘と背後の堆積によって 逆流域が大幅に縮小して, 流速はすぐに水制側側岸 に回り込み，横断方向流速差が減少することがわか る.これに対し，斜め透過型では河床変動が小さい ため，流速場はほとんど変化せず，移動床において も固定床とほぼ同程度の剥離渦を維持していた。

\section{5. 結論}

不透過型, 直進透過型, 斜め透過型の水制を比較 すると違いは以下のとおりである. 不透過型水制は 主流の剥離により水制下流部に大きな剥離渦を形成 し，渦による逆流は強く，水制の破損・水制域の減 少につながる水制頭部の大きな洗掘を起こし，流れ に対する抵抗も大きい. 直進透過型水制は水はね効 果は小さいが, 背後の乱れの減少により横断混合が 抑制され，流速差はかなり長く維持される. 洗掘は 小さく河床変動に与える影響は少ない. ただし剥離 渦はかなり縮小される. 斜め透過型水制はスリット の位置や透過度の組合せによって不透過と同等以上 の循環流域を確保でき, 流れに対する抵抗を小さく する. 斜めの透過流が水制頭部の洗掘を弱め，また 水制背後の渦を安定に保つことができる. 不透過型 では河床変動により水制背後の流れ構造が固定床と は大きく異なるのに対し，斜め透過型では，固定床 で見られる剥離渦が移動床でも維持されや寸い.
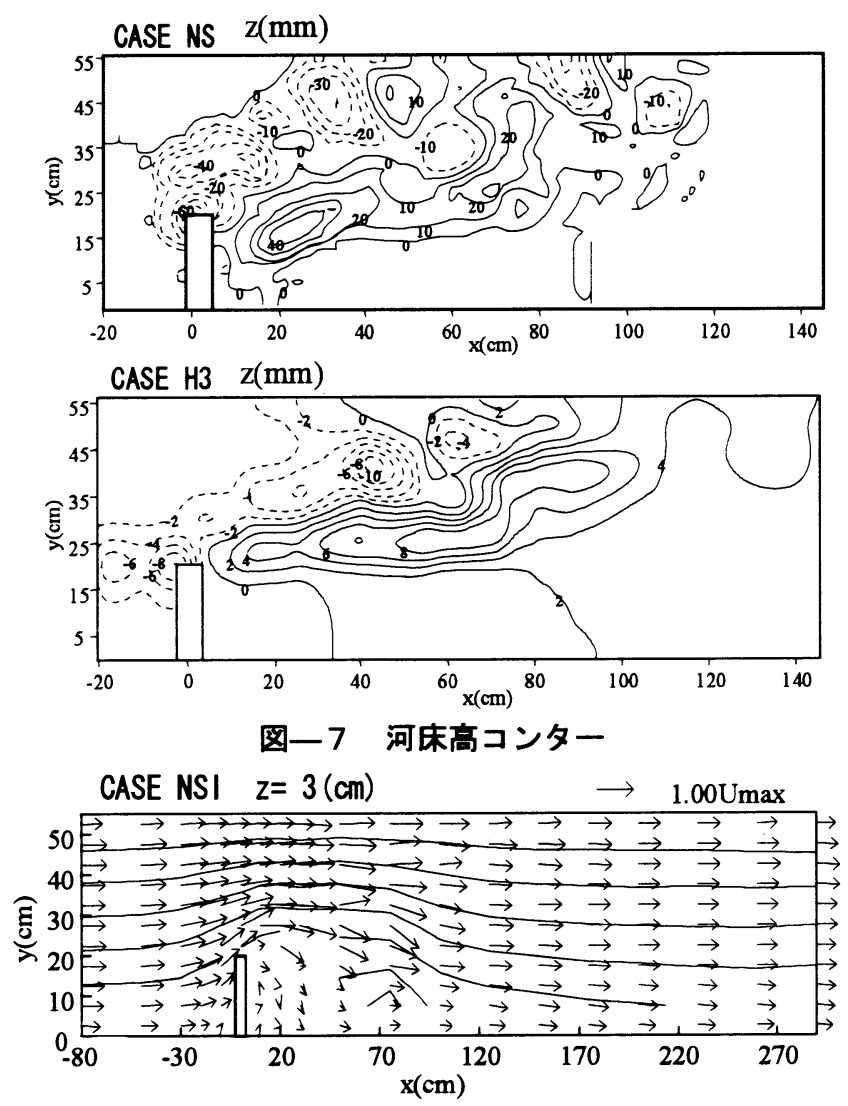

图ー8 河床変動後の流速ベクトル（不透過型）

2) 福岡・渡辺, 西村: 水制工の配置法の研究, 土木学会論 文集, No.443/I-18, pp.27-36, 1992.

3) Klingeman, P.C., Kehe, S.M. and Owusu, Y.A.: Streambank Erosion and Channel Scour Manipulation Using Rockfill Dikes and Gabions. WRRI Report for Project No.373909, Oregon State Univ., pp. 1-169, 1984.

4) 池田・吉池・杉本: 不透過水制群を有する流九構造に関 する実験的研究, 水工学論文集, 43, pp.281-286, 1999.

5) 福岡・岡信・川口・西村:越流型水制周辺の流九之河床変 動, 水工学論文集, 42, pp.997-1002, 1998.

6) 大本・平川・井出:越流型水制群に対寸る二次流と流砂 の応答, 水工学論文集, 42, pp.1003-1008, 1998.

7) 陳・池田: 水制周りの水平剥離渦の構造に関する実験的 研究, 水工学論文集, 40, pp.787-792, 1996.

8) 福岡・渡辺・西村 : 水制工の適切な配置決定のための三次 元モデルの開発，水工学論文集，34，pp.337-342，1990.

9) 崇田・清水 : 水制を含む流れの準 3 次元数值計算モデルの 開発，土木学会論文集，No.497/I-28，pp.31-40，1994.

10) 楊・石井 : 水制に着目した景観デザインの可能性に関 する研究, 第4回河道の水理と河川環境に関するシン ポジウム論文集, pp.111-116, 1998.

11) イヴァン・ニキティン（福留脩文・山脇正俊訳）：水制の 理論と計算一近自然可川工法の発想を助けるために一, 大 学図書, 1995.

12）福岡・渡边・大橋・姫野: 樹木群の水制的利用可能性の研 究，水工学論文集，41，pp.1129-1132, 1997.

13）福岡・檴澤・斎藤・布施・渡边・大橋: 柳水制の訊験施工 とその機能の現地调查，水工学論文集，42，pp.445-450. 